\title{
Evidence of a Role for Mesothelial Cell-derived Interleukin 8 in the Pathogenesis of Asbestos-induced Pleurisy in Rabbits
}

\author{
Alice M. Boylan, ${ }^{\star \$ \|}$ Curzio Rüegg, ${ }^{\star \$ \|}$ K. Jin Kim, Caroline A. Hébert,' John M. Hoeffel, ${ }^{\star}$ Robert Pytela, ${ }^{\star \star \|}$ Dean Sheppard, ${ }^{\star 8 \|}$ \\ Ira M. Goldstein, ${ }^{* *}$ and V. Courtney Broaddus*\$l" \\ ${ }^{*}$ Department of Medicine, ${ }^{\ddagger}$ Rosalind Russell Arthritis Research Laboratory, and ${ }^{\S}$ Lung Biology Center, San Francisco General Hospital; \\ "Cardiovascular Research Institute, University of California, San Francisco, California 94110; and 'Genentech, Inc., South San \\ Francisco, California 94080
}

\section{Abstract}

Although acute asbestos-induced pleurisy is characterized by an influx of neutrophils, the identity of the factors that attract these cells to the pleural space and the source of the factors are unknown. We found that instillation of crocidolite asbestos into the pleural space of rabbits led to the appearance in pleural liquid of chemotactic activity for neutrophils, and that this chemotactic activity was inhibited significantly by a neutralizing antibody to human interleukin 8 (IL-8). Cultured rabbit pleural mesothelial cells incubated with crocidolite asbestos also released chemotactic activity for neutrophils, which was inhibited significantly by the anti-IL-8 antibody. To determine whether rabbit pleural mesothelial cells synthesize IL-8, we generated a probe for rabbit IL-8 mRNA by amplifying cDNA prepared from stimulated pleural mesothelial cells using the polymerase chain reaction (PCR) and primers based on homologous sequences in human and sheep IL-8 cDNAs. Homology-based PCR yielded a single cDNA fragment with a nucleotide sequence $88 \%$ identical to that of a corresponding region of human IL-8 cDNA. With the radiolabeled PCR product as a probe, we demonstrated rapid induction of IL-8 mRNA expression in pleural mesothelial cells exposed to asbestos. As expected, tumor necrosis factor- $\alpha$ also led to the appearance of IL-8 in the rabbit pleural space and stimulated cultured pleural mesothelial cells to synthesize and release IL-8. We conclude that asbestos directly stimulates pleural mesothelial cells to synthesize IL-8 and that mesothelial cell-derived IL-8 may play an important role in mediating asbestos-induced pleural inflammation. (J. Clin. Invest. 1992. 89:1257-1267.) Key words: chemotaxis $\bullet$ pleural effusions $\bullet$ pleurisy $\bullet$ polymerase chain reaction $\bullet$ rabbit neutrophils

Portions of this work were presented at the Annual Meeting of the Western Section of the American Federation for Clinical Research, February 1991, and the 75th Annual Meeting of the Federation of American Societies for Experimental Biology, April 1991, and were published in abstract form (1991. Clin. Res. 39:72A; and 1991. FASEB J. 5:1010).

Address reprint requests to Dr. Broaddus, Room 5K1, Chest Service, San Francisco General Hospital, 1001 Potrero Avenue, San Francisco, CA 94110. 1991

Received for publication 8 July 1991 and in revised form 28 October

J. Clin. Invest.

(c) The American Society for Clinical Investigation, Inc.

$0021-9738 / 92 / 04 / 1257 / 11 \quad \$ 2.00$

Volume 89, April 1992, 1257-1267

\section{Introduction}

The pleura is an important site of asbestos-induced injury in man. When asbestos is instilled into the pleural space of animals, the earliest response is an acute inflammation characterized by an influx of neutrophils. Asbestos is also associated with a persistent neutrophilia $(1,2)$. Indeed, the influx of neutrophils may be a necessary precursor to later manifestations of pleural disease (3). Although the neutrophil influx has been described, neither the identity of the chemotactic factors that attract neutrophils to the pleural space nor their source has been determined. In a study by Shore et al. (4), instillation of crocidolite asbestos into the pleural space of rabbits led to the appearance in pleural liquid of chemotactic activity for neutrophils, which was not affected by prior depletion of complement. The investigators concluded that the unidentified chemotactic activity was produced by resident pleural cells.

Mesothelial cells, which continuously line the pleural spaces, are in an advantageous position to encounter anything entering the pleural spaces and to recruit neutrophils from the vasculature into these spaces. Although previously considered a passive lining cell, pleural mesothelial cells exhibit a variety of functions that suggest that they play a role in the pathogenesis of inflammation. For example, mesothelial cells have been shown to phagocytose particles including asbestos fibers (5), produce prostaglandins in response to nonspecific irritants (6), and express immune-associated antigens in response to interferon- $\gamma$ (7). In a recent report by Antony et al. (8), rabbit pleural mesothelial cells were shown to produce a neutrophil chemotaxin, a $6-9-\mathrm{kD}$ peptide. Although the identity of the peptide was not determined, this work provided evidence that pleural mesothelial cells might be a source of asbestos-induced chemotactic activity.

Interleukin 8 (IL-8), an $8.5-\mathrm{kD}$ peptide, has potent chemotactic activity for neutrophils. There are reasons to suspect both that IL-8 might be a product of mesothelial cells and that IL-8 might be an important mediator induced by exposure to asbestos. For example, IL-8 has been shown to be synthesized not only by hematopoietically derived cells, such as mononuclear phagocytes $(9,10)$, but also by a variety of nonhematopoietically derived cells such as fibroblasts (11), hepatocytes (12), endothelial cells (13), and a pulmonary epithelial cell line (14). In addition, IL-8 is resistant to proteases, its message is longlasting, and it specifically attracts and activates neutrophils. Therefore, IL- 8 may be an important mediator of those types of inflammation characterized by a neutrophil influx, such as that due to asbestos.

We hypothesized that mesothelial cells produce IL-8 in response to asbestos, and that this chemotactic factor plays an important role in the pathogenesis of asbestos-induced pleural 
inflammation. To test this hypothesis, we first used a novel method for continuously monitoring inflammatory responses in vivo to determine whether instilling crocidolite asbestos into the pleural spaces of rabbits led to the appearance in pleural liquid of chemotactic activity. Second, we tested whether chemotactic activity generated in vivo could be inhibited by a neutralizing antibody to IL-8. Third, we exposed cultured rabbit pleural mesothelial cells to asbestos to determine whether these cells release chemotactic activity that also could be inhibited by the anti-IL-8 antibody. Fourth, we developed a probe for rabbit IL-8 mRNA to determine whether asbestos induces IL-8 mRNA expression in mesothelial cells. Finally, in order to generalize our findings to other types of inflammation, we repeated the experiments in vitro and in vivo, using as a stimulus the macrophage-derived cytokine, tumor necrosis factor- $\alpha$ (TNF). ${ }^{1}$

\section{Methods}

Studies in vivo. 21 healthy male New Zealand white rabbits $(2.6 \pm 0.3$ $\mathrm{kg}$ ) were anesthetized with halothane, intubated via tracheostomy, and ventilated with $60 \%$ oxygen $/ 1 \%$ halothane at an inspiratory pressure of $18 \mathrm{cmH}_{2} \mathrm{O}$ (end-expiratory pressure of $5 \mathrm{cmH}_{2} \mathrm{O}$ ). Each rabbit was placed supine for insertion of carotid artery and jugular venous catheters, as well as bilateral pleural catheters. The pleural catheter had been prepared by flaring the tip of a PE-160 catheter (Clay Adams, Parsippany, NJ), sealing the opposite end with a rubber adapter, gas sterilizing, and flushing with RPMI-1640 (GIBCO, Grand Island, NY). The pleural catheters were placed sterilely, as follows (15). After the upper abdomen was opened to expose the diaphragm, the ventral diaphragmatic muscle was bluntly dissected $1 \mathrm{~cm}$ lateral to the midline on each side to expose the diaphragmatic pleura and underlying lung. Through a small hole in the pleura, the flared tip of the catheter was introduced, secured in place by a purse-string suture and two circumferential ties, and pulled back flush with the diaphragm. All air (0.2-1.5 $\mathrm{ml}$ ) was aspirated. After the two catheters were placed and the abdomen closed, the rabbit was placed prone with the catheters projecting through a hole in a supporting board.

The control instillate was prepared from RPMI-1640 cell culture medium with added human serum albumin $(0.1 \mathrm{~g} / \mathrm{dl})$ and calcium gluconate ( $3 \mathrm{meq} / \mathrm{liter}$ ) (GIBCO). For the experimental instillates, crocidolite asbestos (National Institute of Environmental Health and Safety, Research Triangle Park, NC) (16) or recombinant human TNF ( $R$ \& D Systems Inc., Minneapolis, $M N$ ) was added to a final concentration of $30 \mu \mathrm{g} / \mathrm{ml}$ or $20 \mathrm{ng} / \mathrm{ml}$, respectively. The crocidolite asbestos (mean width, $0.25 \mu \mathrm{m}$; mean length, $19 \mu \mathrm{m}$ [16]) had been washed three times with endotoxin-free water, baked at $300^{\circ} \mathrm{C}$ for $12 \mathrm{~h}$, and autoclaved. The concentrated stock samples of asbestos and TNF were found to contain undetectable levels of endotoxin using a Limulus assay (Whittaker Bioproducts, Walkersville, MD), indicating that $<1.0 \mathrm{pg} / \mathrm{ml}$ endotoxin was present in the dilutions used in vivo. For additional control experiments, instillates either with glass beads, asbestos filtrate or asbestos with polymixin were prepared. Glass beads (diameter, $2.1 \pm 0.9 \mu \mathrm{m}$ [mean \pm SD]; Duke Scientific Corp., Palo Alto, CA), washed, baked, and autoclaved as above, were added to an RPMI1640 control instillate to a final concentration of $30 \mu \mathrm{g} / \mathrm{ml}$ (mean bead count $15,125 / \mu \mathrm{l})$. Asbestos filtrate was obtained by preparing an asbestos instillate as above, allowing it to stand for $10 \mathrm{~min}$ and then slowly filtering twice (Acrodisc, $0.2 \mu \mathrm{m}$, Gelman Sciences Inc., Ann Arbor, MI); after filtration, no asbestos fibers could be seen on repeated examination using a hemocytometer $(<1 \mathrm{fiber} / \mu \mathrm{l})$. Polymixin B sulfate (25,000 U; Burroughs-Wellcome, Research Triangle Park, NC) was

1. Abbreviation used in this paper: TNF, tumor necrosis factor- $\alpha$. added to asbestos instillates at a concentration sufficient to neutralize $\geq 10 \mu \mathrm{g}$ of endotoxin by Limulus assay. All instillates were adjusted to pH 7.4 and warmed to $39^{\circ} \mathrm{C}$.

During a 30-min baseline period, arterial and venous blood pressures and rectal temperature were recorded every $15 \mathrm{~min}$, and arterial blood was obtained for measuring blood gases and for preparing a plasma sample. At the start of the 6-h experimental period, ${ }^{125}$ I-human serum albumin ( $4 \mu \mathrm{Ci})$ (Merck-Frosst, Kirkland, Quebec) was injected intravenously as a protein marker. The rabbit then was tilted $15^{\circ}$ head up and baseline pleural liquid samples $(0.1 \mathrm{ml})$ were withdrawn through the catheters before the instillates $(10 \mathrm{ml})$ were injected into each pleural space. In the control experiments $(n=5)$, control instillates were injected bilaterally. In the asbestos $(n=5), \operatorname{TNF}(n=5)$, glass bead $(n=2)$, or asbestos filtrate $(n=2)$ experiments, the instillate containing the test substance was injected into one pleural space chosen at random (8 on right, 6 on left), and the control instillate was injected into the opposite pleural space. In the asbestos plus polymixin experiments $(n=2)$, the instillate containing asbestos plus polymixin was injected into one pleural space and the instillate containing asbestos alone was injected into the opposite pleural space. After instillation, each pleural catheter was cleared with $0.1 \mathrm{ml}$ air, and the rabbit was returned to a level position. A portion of each instillate was saved for later measurements of chemotactic activity and endotoxin concentration. By Limulus assay, endotoxin was undetectable in all instillate samples.

During each experiment, pleural liquid samples $(1.0 \mathrm{ml})$ were withdrawn at $0,1,2,3,4$, and $6 \mathrm{~h}$. Vascular pressures and temperature were recorded every $15 \mathrm{~min}$, and blood samples were obtained hourly. After $6 \mathrm{~h}$, the rabbit was exsanguinated, and the chest was opened. A drop of liquid was cultured aerobically (none of the cultures yielded growth after $48 \mathrm{~h}$ of incubation). All available pleural liquid was aspirated and the space lavaged twice with one $10-\mathrm{ml}$ aliquot of sterile saline.

After saving a portion for cell and differential counts and asbestos fiber counts, all pleural liquid samples were centrifuged and supernatants frozen at $-70^{\circ} \mathrm{C}$ for later chemotaxis studies. White and red blood cells and asbestos fibers in undiluted samples of pleural liquid and lavage were counted using a hemacytometer, and differential counts were determined after May-Grünwald staining of cytocentrifuged samples. Radioactivity of pleural liquid and lavage samples was determined by gamma scintillation counting.

Total cell counts and radioactivity were calculated as the counts in the available pleural liquid plus those in the lavage. To assess pleural microvascular permeability to protein, plasma equivalents (ml), i.e., the minimum plasma volume that could account for the pleural radioactivity, were calculated (total pleural radioactivity [cpm] divided by the average plasma radioactivity $[\mathrm{cpm} / \mathrm{ml}])$.

Rabbit pleural mesothelial cell cultures. Pleural mesothelial cells were harvested by instilling trypsin $(0.25 \%, \mathrm{wt} / \mathrm{vol})$ into the pleural spaces of anesthetized New Zealand white rabbits as described previously (8). All cells were incubated at $37^{\circ} \mathrm{C}$ in an atmosphere of $5 \% \mathrm{CO}_{2}$ in medium consisting of equal parts Dulbecco's modified Eagle's medium and RPMI-1640, containing gentamicin $(0.05 \%$, wt $/ \mathrm{vol})$ and heat-inactivated fetal bovine serum (10\%, vol/vol) (GIBCO). After discrete colonies were established (5-7 d), mesothelial cells were separated from rare contaminating fibroblasts by the greater susceptibility of the mesothelial cells to removal from the culture dishes by treatment with trypsin $(0.25 \%, w t / v o l)$. The identity of the cells and their purity were verified by negative immunohistochemical staining with polyclonal antibodies to factor VIII antigen (Dako Corp., Santa Barbara, CA) (Fig. 1 $a$ ), by positive immunohistochemical staining with monoclonal antibodies to both keratin (AE1 and AE3, Boehringer-Mannheim Corp., Indianapolis, IN) and vimentin (Accurate Chemical and Scientific Corp., Westbury, NJ) (Fig. 1, $b$ and $c$ ), by the presence of numerous long microvilli on electron microscopy, and by negative staining for nonspecific esterase. To check the validity of the factor VIII antibody for rabbit cells, we confirmed that rabbit aortic endothelial cells in culture and in tissue section stained positively with the polyclonal antibodies to factor VIII. To check the specificity of vimentin and keratin 


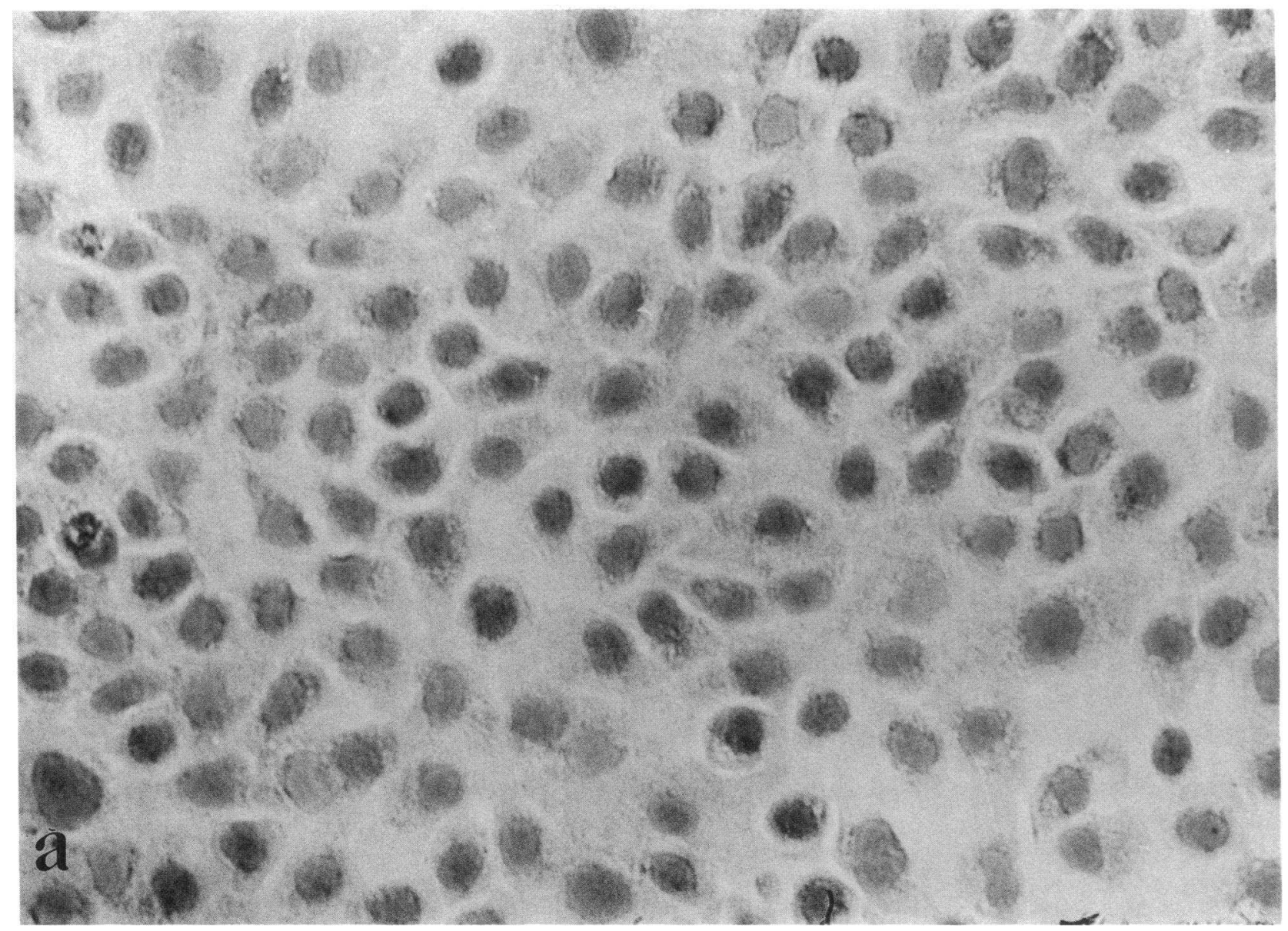

Figure 1. Immunohistochemical staining of cultured rabbit pleural mesothelial cells for $(a)$ factor VIII, $(b)$ keratin, and $(c)$ vimentin (original magnification $\times 500$ ). Above: Section $a$.

coexpression, we lavaged a rabbit lung and confirmed that alveolar macrophages stained only for vimentin, and ciliated bronchial epithelial cells stained only for keratin. Finally, to exclude the presence of macrophages in our cultures, we stained cultured mesothelial cells for nonspecific esterase using rabbit alveolar and peritoneal macrophages as positive controls. Macrophages demonstrated homogeneous and intense staining for esterase, but in 100 fields of cultured cells $(25 \times$ magnification), we found no cells showing homogeneous staining for esterase signifying fewer than one macrophage per 20,000 mesothelial cells.

Exposure of mesothelial monolayers to asbestos or TNF. Confluent monolayers of rabbit pleural mesothelial cells (passage 2-6) were washed three times with phosphate-buffered saline and then incubated with serum-free medium (RPMI-1640) for $6 \mathrm{~h}$. After 0,2 , or $4 \mathrm{~h}$, crocidolite asbestos $(30 \mu \mathrm{g} / \mathrm{ml})$ or TNF $(20 \mathrm{ng} / \mathrm{ml})$ was added. For additional control experiments, after $4 \mathrm{~h}$, glass beads $(30 \mu \mathrm{g} / \mathrm{ml})$ or the filtrate from crocidolite asbestos $(30 \mu \mathrm{g} / \mathrm{ml})$ was added. As a result, all cells were exposed to serum-free medium alone for $6 \mathrm{~h}$ or to stimuli for 2,4 , or $6 \mathrm{~h}$. After $6 \mathrm{~h}$, samples of conditioned media were centrifuged and supernatants were frozen at $-70^{\circ} \mathrm{C}$; the cells were harvested for RNA extraction (see below). Cell integrity was determined at the end of each experiment by phase-contrast microscopy and by measuring lactate dehydrogenase activity in medium from cells cultured with and without stimuli using a kit from Sigma Chemical Co. (St. Louis, MO). Results are expressed as a percent of the total lactate dehydrogenase activity released from an equal number of cells lysed with $1.0 \%$ (vol/ vol) Triton X-100 (Sigma Chemical Co.).

Preparation of rabbit neutrophils. Blood $(10 \mathrm{ml})$ was aspirated from the central ear artery of rabbits into acid-citrate-dextrose $(2.5 \mathrm{ml})$. Neutrophils were isolated by centrifugation of anticoagulated blood $(100 \mathrm{~g}$ for $1 \mathrm{~h}$ at $\left.10^{\circ} \mathrm{C}\right)$ in dextran $(1.5 \%$, wt/vol, molecular weight of 200,000 300,000 ) (Eastman Kodak Co., Rochester, NY). The neutrophil-rich layer was gently aspirated, exposed to distilled water for $30 \mathrm{~s}$ to lyse contaminating erythrocytes, and sedimented by centrifugation $(700 \mathrm{~g}$ for $10 \mathrm{~min}$ ). After washing with phosphate-buffered saline, pelleted neutrophils were resuspended at a density of $3 \times 10^{6} \mathrm{cells} / \mathrm{ml}$ in buffer, i.e., Hanks' balanced salt solution with calcium and magnesium (GIBCO), containing 1\% (wt/vol) bovine serum albumin (Sigma Chemical Co.). Cell viability exceeded $96 \%$ as determined by exclusion of trypan blue dye $(0.4 \%$, wt/vol) (GIBCO).

Measurement of chemotactic activity. Directed migration (i.e., chemotaxis) and random migration of rabbit neutrophils were measured using minor modifications of the "leading front" method of Zigmond and Hirsch (17). Briefly, duplicate samples of conditioned media at various dilutions, FMLP (1.0 nM, Sigma Chemical Co.) or buffer alone, were placed in the lower wells of a blind-well microchemotaxis chamber (Neuro Probe Inc., Cabin John, MD). A nitrocellulose filter (3 $\mu \mathrm{m}$-pore diameter, Neuro Probe) was placed in the assembly on top of the conditioned media, and $50 \mu \mathrm{l}$ of the neutrophil suspension was added to each of the upper wells. The wells were covered and the chemotaxis chamber was incubated for $40 \mathrm{~min}$ at $37^{\circ} \mathrm{C}$ in humidified $95 \%$ air $/ 5 \% \mathrm{CO}_{2}$. The filters were removed, fixed in methanol, and stained with Giemsa (Sigma Chemical Co.). The leading front of migrating neutrophils was measured as the farthest distance from the upper surface of the filter that the nuclei of two neutrophils could be seen clearly. For each sample, the leading front was determined by making six random measurements at high power $(100 \times)$ on each of two duplicate filters, eliminating the highest and lowest values, and averaging the remaining 10 values. All measurements were blinded. Chemotactic 


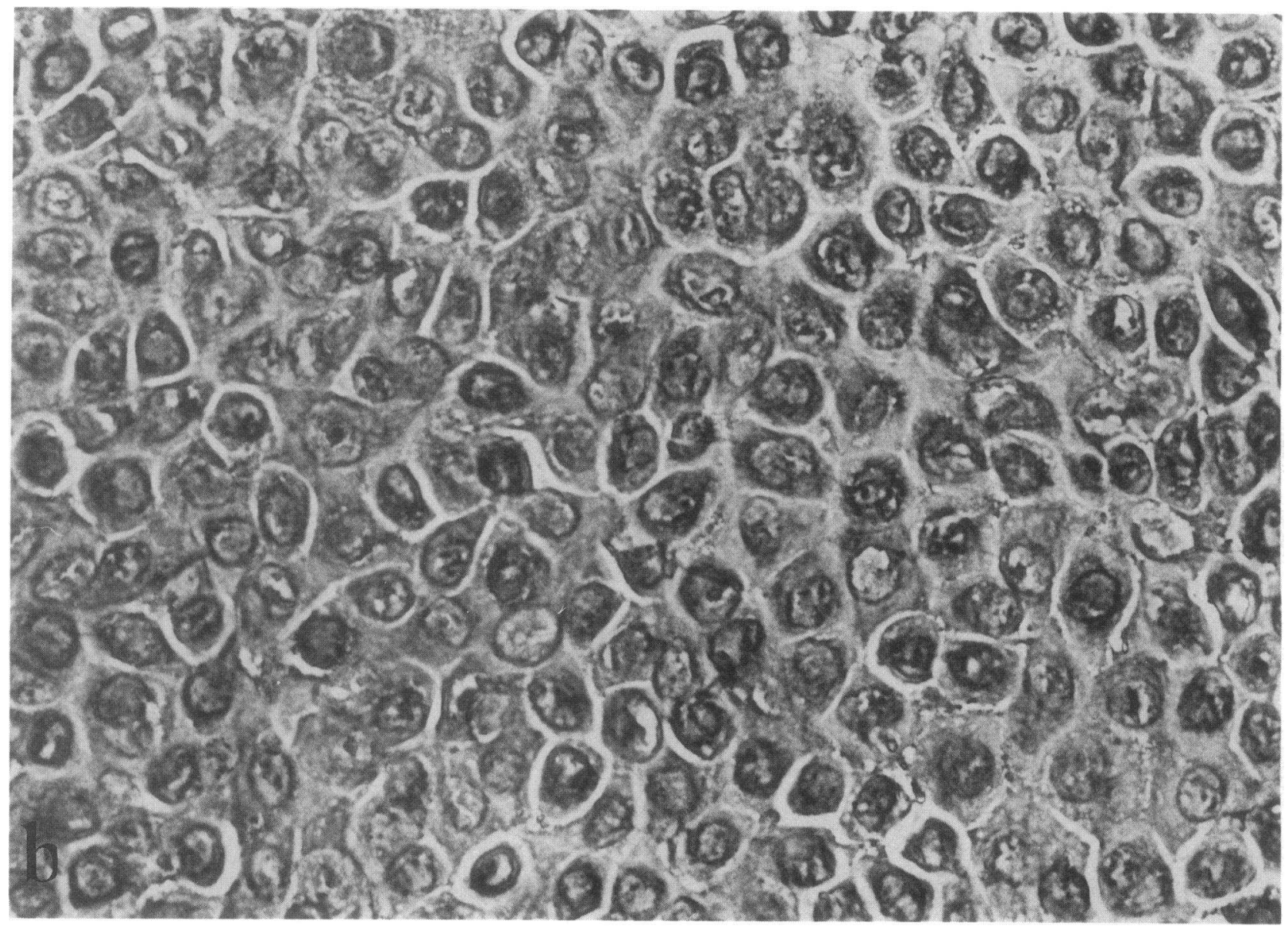

Figure 1 (Continued). Section $b$.

activity is expressed as net neutrophil migration $(\mu \mathrm{m} / 40 \mathrm{~min})$, i.e., the distance neutrophils migrated in response to a stimulus minus the distance they migrated in response to buffer alone (i.e., random migration). A "checkerboard analysis" to distinguish directed migration (chemotaxis) from stimulated random migration (chemokinesis) was performed by measuring migration of neutrophils in response to various concentrations $(100 \%, 10 \%, 1 \%$, and $0 \%)$ of conditioned medium in the lower and upper wells (17). In addition to samples of pleural liquid or conditioned medium, tested samples included cell culture medium alone, asbestos alone ( $30 \mu \mathrm{g} / \mathrm{ml})$ and TNF- $\alpha$ alone (20 $\mathrm{ng} / \mathrm{ml})$.

Neutralization studies. For neutralization studies, samples of pleural liquid or conditioned media were incubated with $100 \mu \mathrm{g} / \mathrm{ml}$ of either a murine monoclonal anti-human IL-8 antibody (A.5.12.14, $\left.\mathrm{IgG}_{2 \mathrm{a}}\right)\left(\right.$ Genentech, Inc., South San Francisco, CA), $\mathrm{F}\left(\mathrm{ab}^{\prime}\right)_{2}$ fragments of this antibody, an isotype-matched murine myeloma protein (RPC 5, Bionetics Laboratory Products, Charleston, $\mathrm{SC}$ ) or $\mathrm{F}\left(\mathrm{ab}^{\prime}\right)_{2}$ fragments of a murine monoclonal anti-IL-6 antibody (Genentech) for $30 \mathrm{~min}$ at $37^{\circ} \mathrm{C}$ and then assayed for chemotactic activity. Because of a limited supply during the study period, the $\mathrm{F}\left(\mathrm{ab}^{\prime}\right)_{2}$ antibody fragments were used for the asbestos studies only. MAb A.5.12.14 reacts equally well with the 77- and 72-amino acid forms of human IL-8, does not crossreact with closely related members of the macrophage inflammatory protein family (i.e., platelet factor 4 and $\beta$-thromboglobulin), and blocks the ability of human IL-8 to induce chemotaxis and changes in cytosolic calcium in human neutrophils (Hébert, C. A., and K. J. Kim, unpublished observations).

Homology-based PCR. To isolate a cDNA fragment that encodes rabbit IL-8, total mesothelial cell RNA was reverse-transcribed and the resulting cDNA was used as a template in a homology-based PCR. Total cellular RNA was first isolated from TNF-stimulated $(20 \mathrm{ng} / \mathrm{ml}$,
$24 \mathrm{~h}$ ) and unstimulated rabbit pleural mesothelial cells as follows. Cultured cells $\left(\sim 1.6-1.9 \times 10^{7}\right)$ were washed, lysed in $3 \mathrm{M} \mathrm{LiCl} / 6 \mathrm{M}$ urea, homogenized, stored overnight at $4^{\circ} \mathrm{C}$, and then centrifuged $(11,000 \mathrm{~g}$ for $60 \mathrm{~min}$ at $4^{\circ} \mathrm{C}$ ). The pelleted material was dissolved in $10 \mathrm{mM}$ Hepes/1.0 mM EDTA/1.0\% (wt/vol) SDS, and then extracted with phenol/chloroform (1:1). RNA was recovered from the aqueous phase by sodium acetate/ethanol precipitation and subsequently dissolved in RNase-free water.

RNA (50-55 $\mu \mathrm{g}$ ) was then reverse-transcribed using random hexamer primers and RNase H-negative Maloney murine leukemia virus reverse transcriptase (300 U) (Bethesda Research Laboratories, Gaithersburg, MD) in a 30- $\mu$ l reaction volume. Homology-based PCR was then performed using the cDNA generated by reverse transcription as a template and two degenerate, synthetic oligonucleotide primers. The oligonucleotide primers were designed to be complementary to homologous regions of human (18) and sheep IL-8 cDNA (Talhouk, A., and I. M. Goldstein, unpublished observations) and to contain recognition sites (underlined) for the restriction enzymes, EcoRI and SalI, at their 5 ' ends, as follows:

\section{5'-AGAGAATTCGAA(G)C(T)TICGITGC(T)}

CAA(G)TGC(T)A(C)TIAA-3' (forward)

and

\section{5'-ACAGTCGACT(C)TGIACCCAITTC(T)}

TCITTIGGA(G)TCIAA(G)A(G)CA-3' (reverse).

Reaction mixtures contained the reverse-transcribed cDNA $(2 \mu 1)$, both primers $(1.0 \mu \mathrm{M}$ each), dATP, dGTP, dCTP, and dTTP (0.1 mM each), Taq DNA polymerase (3 U) (Promega Biotec, Madison, WI), and PCR 


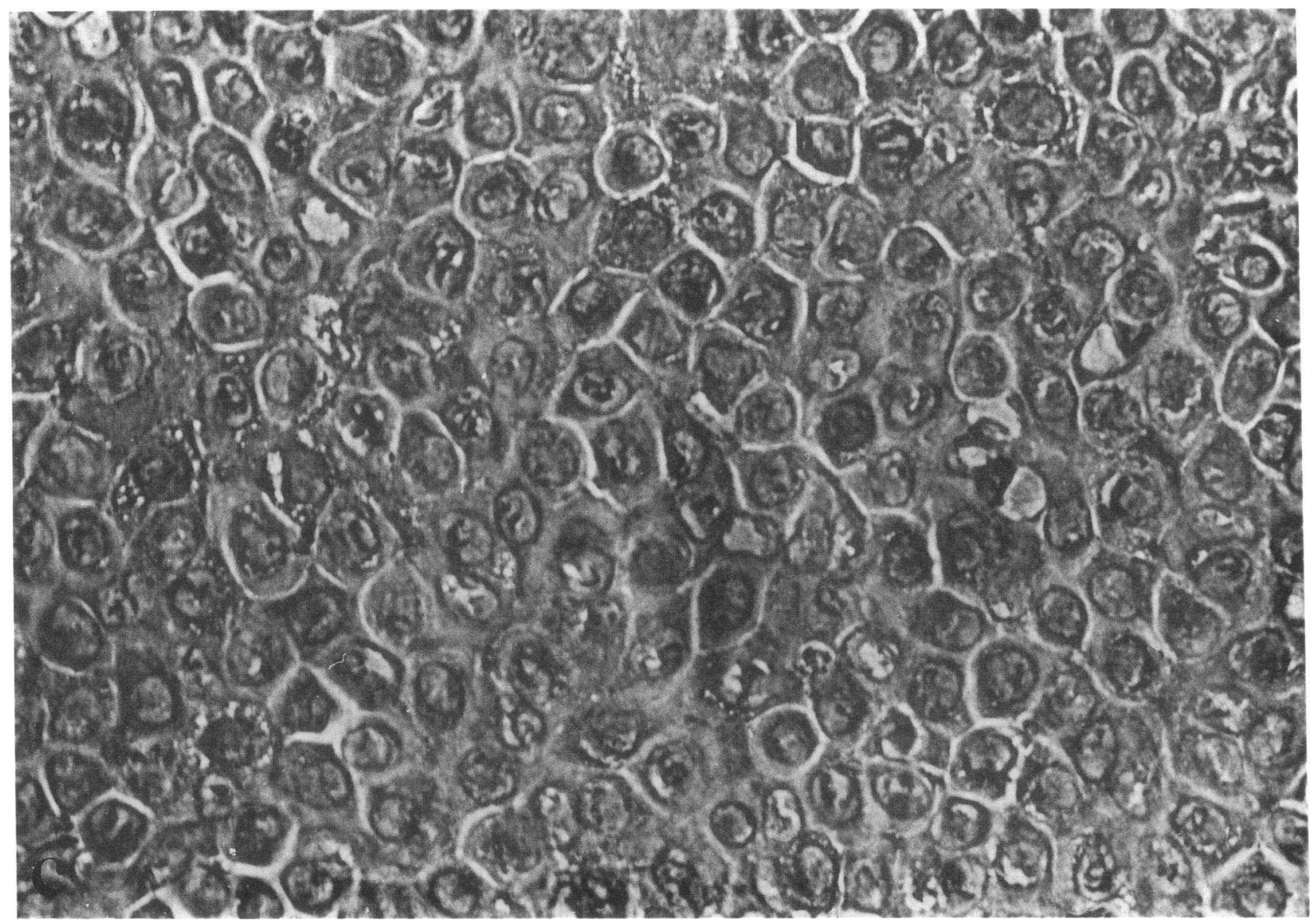

Figure 1 (Continued). Section $c$.

buffer $\left(50 \mathrm{mM} \mathrm{KCl}, 10 \mathrm{mM}\right.$ Tris- $\mathrm{HCl}\left[\mathrm{pH} 9.0\right.$ at $25^{\circ} \mathrm{C}$, $1.5 \mathrm{mM}$ $\mathrm{MgCl}_{2}, 0.01 \%$ gelatin, and $0.1 \%$ Triton X-100). Reaction mixtures (total volume $100 \mu \mathrm{l}$ ) were overlayed with mineral oil, heated to $95^{\circ} \mathrm{C}$ for $4 \mathrm{~min}$ in a thermal cycler (Ericomp Inc., San Diego, CA), and then subjected to 30 cycles of denaturation at $95^{\circ} \mathrm{C}$ for $45 \mathrm{~s}$, annealing at $48^{\circ} \mathrm{C}$ for $45 \mathrm{~s}$, and extension at $72^{\circ} \mathrm{C}$ for $1 \mathrm{~min}$. Immediately after the last cycle, the sample was maintained at $72^{\circ} \mathrm{C}$ for $10 \mathrm{~min}$ and then extracted with phenol/chloroform. DNA recovered after precipitation with sodium acetate/ethanol was digested with EcoRI and Sall (Promega Biotec) and then electrophoresed in low-melting-point agarose (1.5\%, Bio-Rad Laboratories, Richmond, CA). Relevant portions of the gel were excised, melted at $68^{\circ} \mathrm{C}$ for $10 \mathrm{~min}$, placed at $37^{\circ} \mathrm{C}$ for 3 min, extracted with phenol/chloroform, and mixed with sodium acetate/ethanol to precipitate the DNA.

Cloning and sequencing. Purified DNA from the PCR $(\sim 100-200$ ng) was ligated into pBluescript (Stratagene Inc., La Jolla, CA) that had been digested with EcoRI and SalI, and the product was used to transform competent Escherichia coli (JM-109, Clontech, Palo Alto, CA). Plasmids containing inserts were purified from the $E$. coli using alkaline lysis (Pharmacia Miniprep Lysis Kit, Pharmacia-LKB Biotechnology, Piscataway, NJ), denatured in $0.3 \mathrm{M} \mathrm{NaOH}$, and further purified on columns of Sephacryl S-400 (Pharmacia). Sequencing of both strands was carried out by the dideoxynucleotide chain-termination procedure (19), using modified T7 polymerase (Stratagene) and primers complementary to the $\mathrm{T} 3$ and $\mathrm{T} 7$ promoter sequences of pBluescript (Stratagene).

Northern blot analysis. Total RNA from stimulated and unstimulated mesothelial cells was analyzed for IL-8 mRNA expression using the labeled rabbit IL-8 $\mathrm{cDNA}$ fragment as a probe. Total RNA $(\sim 20$ $\mu \mathrm{g})$ was electrophoresed in agarose gels $(1.0 \%)$ containing formaldehyde $(2 \%, \mathrm{vol} / \mathrm{vol})$ and transferred to Hybond-N nylon membranes (Amersham Corp., Arlington Heights, IL) by capillary action. Mem- branes were prehybridized in $5 \times$ SSC, $40 \%$ formamide, $5 \times$ Denhardt's solution, $20 \mathrm{mM}$ Tris (pH 7.5), and sheared salmon sperm DNA (100 $\mu \mathrm{g} / \mathrm{ml}$ ) at $50^{\circ} \mathrm{C}$ for $1 \mathrm{~h}$. The ${ }^{32} \mathrm{P}$-labeled probe was generated by using the rabbit IL-8 cDNA PCR product as a template for random-primed synthesis (Multiprime DNA labeling system, Amersham Corp.). Filters were hybridized overnight at $50^{\circ} \mathrm{C}$ in fresh prehybridization buffer supplemented with $10 \%$ dextran sulfate (Sigma) and the denatured, ${ }^{32} \mathrm{P}$-labeled cDNA probe (sp act $0.5-1.0 \times 10^{9} \mathrm{cpm} / \mu \mathrm{g}$ ). Filters were then washed $\left(2 \times\right.$ SSC briefly, $2 \times$ SSC with $0.1 \%$ SDS at $50^{\circ} \mathrm{C} \times 30 \mathrm{~min}$, then $2 \times \mathrm{SSC}$ with $0.5 \% \mathrm{SDS}$ at $50^{\circ} \mathrm{C} \times 30 \mathrm{~min}$ ), and subjected to autoradiography. Filters subsequently were stripped (in $0.1 \times \mathrm{SSC}$ at $95^{\circ} \mathrm{C}$ for 10 min) and hybridized with a radiolabeled $\beta$-actin partial cDNA probe from rat pC12 cells (generous gift of Dr. Michael Miles, University of California, San Francisco) to assess the amounts of mRNA loaded onto the gels.

Statistics. Data from the checkerboard analysis were analyzed using the paired Student's $t$ test to compare the distances neutrophils migrated in response to conditioned medium in the lower well only (positive gradient) and the distances cells migrated when concentrations of conditioned medium in the upper and lower wells of the chemotaxis chamber were the same (no gradient). Differences with respect to time were determined by analysis of variance with repeated measures design (20). Differences among more than one group were analyzed by oneway analysis of variance, with Tukey's test to determine where the differences lay (21). We considered a difference to be significant if $P$ $<0.05$.

\section{Results}

Effects of instilling asbestos or TNF into the pleural spaces of rabbits. Baseline pleural liquid samples of all experiments contained $1,900 \pm 1,400$ total white blood cells/ $\mu$ l, with $24 \pm 8 \%$ neu- 
trophils (mean $\pm \mathrm{SD}, n=42$ pleural spaces), similar to reported normal values (22). In the pleural spaces into which asbestos was instilled, the neutrophil count increased significantly at $3 \mathrm{~h}$ compared with that in the opposite pleural spaces and in the pleural spaces of control rabbits (Fig. $2 A$ ). By $6 \mathrm{~h}$, the total number of neutrophils in the pleural spaces with asbestos was 10-fold higher than in the opposite and control pleural spaces (Table I). Asbestos was the only stimulus that induced an increase in the entry of protein into the pleural space: $0.35 \pm 0.10$ $\mathrm{ml}$ plasma equivalents $(n=5)$ versus $0.19 \pm 0.05 \mathrm{ml}$ on the opposite side $(n=5)$ and $0.17 \pm 0.03$ for control experiments $(n$ $=10$ pleural spaces). The increased protein leak was not accounted for by the entry of blood because the number of erythrocytes was $<1500$ cells $/ \mu$ l and was not greater in the pleural spaces exposed to asbestos. Immediately after instillation, asbestos fiber counts were $11,060 \pm 3,048$ fibers $/ \mu 1$, which decreased to $280 \pm 450$ fibers $/ \mu \mathrm{l}$ by $3 \mathrm{~h}(2.5 \%$ of the initial). At $6 \mathrm{~h}$, $<1 \%$ of the original number of fibers could be retrieved from the pleural space, either by aspiration or lavage. Polymixin did not reduce the neutrophil influx to asbestos; the total number of neutrophils recovered $6 \mathrm{~h}$ after asbestos plus polymixin was not different from the number after asbestos alone on the op-
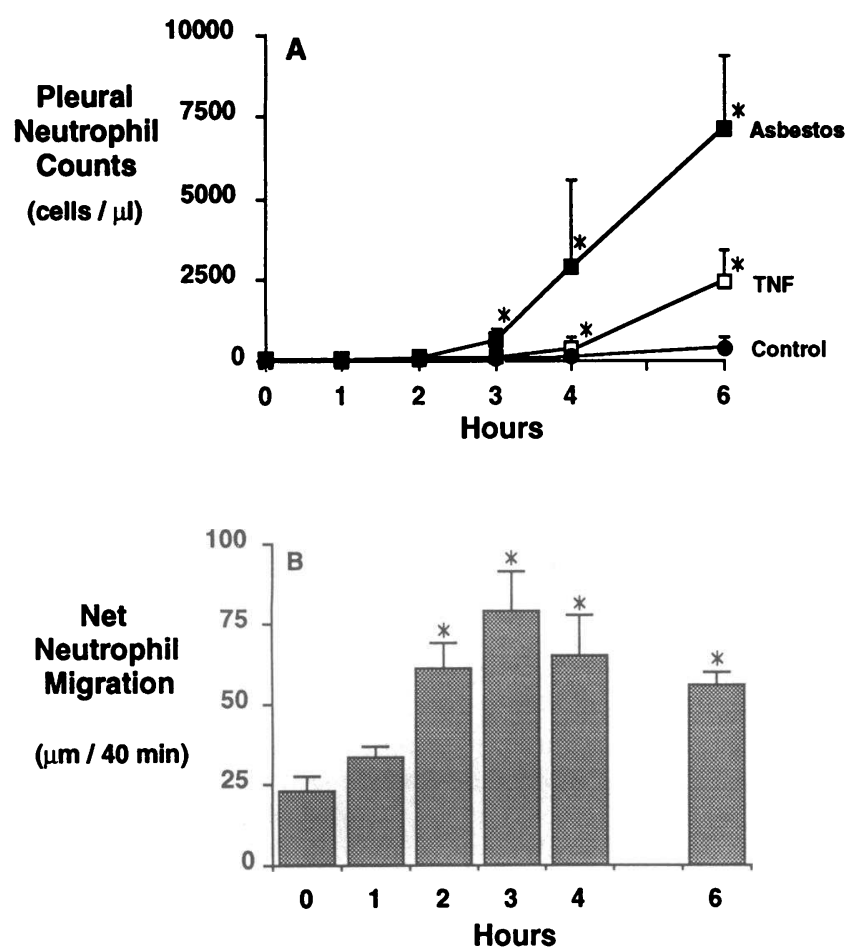

Figure 2. (A) Neutrophil counts in pleural liquid withdrawn from rabbit pleural spaces after asbestos $(30 \mu \mathrm{g} / \mathrm{ml})$ or TNF $(20 \mathrm{ng} / \mathrm{ml})$ was instilled, compared with those from the pleural spaces of control animals (mean \pm SE, $n=5$ rabbits in each group). *Neutrophil counts in pleural liquids from animals exposed to asbestos were significantly greater than those in pleural liquids from control animals at 3,4, and $6 \mathrm{~h}$. *Neutrophil c sunts in pleural liquids from animals exposed to TNF were significantly greater than those in pleural liquids from control animals only at 4 and $6 \mathrm{~h}$. (B) Chemotactic activity in pleural liquid withdrawn from rabbit pleural spaces after asbestos $(30 \mu \mathrm{g} / \mathrm{ml})$ was instilled. Results represent net neutrophil migration ( $\mu \mathrm{m} / 40 \mathrm{~min})$ and are mean values $( \pm \mathrm{SE})$ obtained in five experiments. Chemotactic activity was detectable at $2 \mathrm{~h}$ and was maximal at $3 \mathrm{~h}$. *Significantly different from 0-h sample. Net neutrophil migration in response to $1.0 \mathrm{nM}$ FMLP in these experiments was $54 \pm 8 \mu \mathrm{m} / 40 \mathrm{~min}$.
Table I. Total Neutrophils Recovered from Rabbit Pleural Spaces $6 \mathrm{~h}$ after Asbestos, TNF, or Control Substances Were Instilled

\begin{tabular}{lccc}
\hline & & \multicolumn{2}{c}{ Total neutrophils } \\
\cline { 3 - 4 } & $\begin{array}{l}\text { No. of } \\
\text { rabbits }\end{array}$ & Experimental side & Opposite side \\
\hline & & \multicolumn{2}{c}{$\times 10^{6}$} \\
Asbestos & 5 & $23.8 \pm 10.1^{*}$ & $2.2 \pm 0.5$ \\
TNF & 5 & $10.3 \pm 2.7^{\dagger}$ & $2.8 \pm 1.5$ \\
Medium alone & 5 & $1.9 \pm 1.2$ (right) & $1.9 \pm 2.0$ (left) \\
Glass beads & 2 & $0.8 \pm 0.5$ & $0.6 \pm 0.1$ \\
Asbestos filtrate & 2 & $0.8 \pm 0.9$ & $0.9 \pm 0.4$
\end{tabular}

Total neutrophil counts in pleural liquid plus lavage fluid collected $6 \mathrm{~h}$ after instillation of asbestos $(30 \mu \mathrm{g} / \mathrm{ml})$ or TNF $(20 \mathrm{ng} / \mathrm{ml})$ were compared with that in pleural liquid and lavage fluid from the opposite pleural spaces of the same rabbits and from the pleural spaces of rabbits after instillation of RPMI cell culture medium alone, glass beads $(30 \mu \mathrm{g} / \mathrm{ml})$, or filtrates from asbestos instillates. Data represent mean values \pm SD. * Different from opposite pleural spaces and all other groups by analysis of variance; ${ }^{\dagger}$ Different from opposite pleural spaces and control pleural spaces by analysis of variance $(P=0.0001)$.

posite side (asbestos plus polymixin, $10.3 \pm 5.3 \times 10^{6}$ neutrophils vs. asbestos alone, $6.7 \pm 0.8 \times 10^{6}$ neutrophils; $n=2$ ).

By $2 \mathrm{~h}$ after asbestos was instilled, pleural liquid induced a significant increase in neutrophil migration compared with liquid collected at $0 \mathrm{~h}$ (Fig. $2 \mathrm{~B}$ ). When pleural liquid collected $3 \mathrm{~h}$ after instillation of asbestos was incubated with $F\left(a b^{\prime}\right)_{2}$ fragments of the anti-IL-8 MAb A.5.12.14 $(100 \mu \mathrm{g} / \mathrm{ml})$ for $30 \mathrm{~min}$ at $37^{\circ} \mathrm{C}$, its ability to induce directed migration of neutrophils was reduced by $72 \pm 8 \%$ (mean $\pm \mathrm{SE}, n=5$ ) (Fig. 3). Incubation with $\mathrm{F}\left(\mathrm{ab}^{\prime}\right)_{2}$ fragments of the control, anti-IL-6 MAb $(100 \mu \mathrm{g} /$ $\mathrm{ml})$ had no significant effect $(9 \pm 7 \%$ reduction).

By $4 \mathrm{~h}$ after TNF was instilled in one pleural space, the neutrophil count in the pleural liquid was slightly but significantly greater than that in the pleural liquid from the opposite or control pleural spaces (Fig. $2 A$ ). At $6 \mathrm{~h}$, the total number of

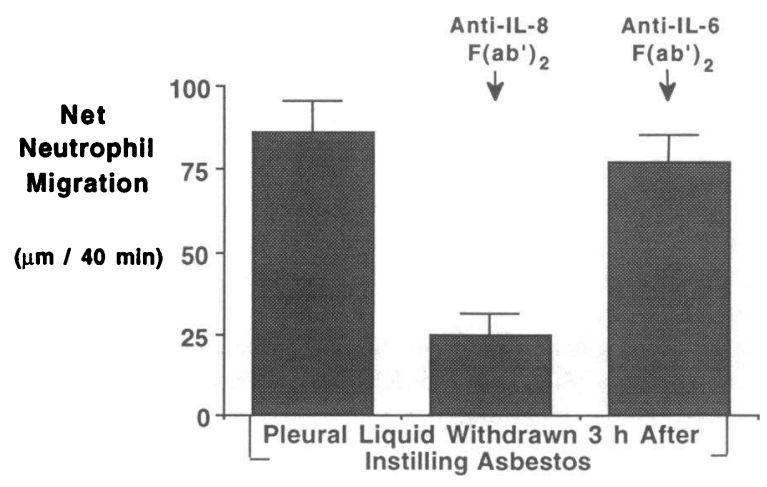

Figure 3. Neutralization of asbestos-induced chemotactic activity in pleural liquid with $\mathrm{F}\left(\mathrm{ab}^{\prime}\right)_{2}$ fragments of the anti-IL-8 MAb, A.5.12.14 Incubation of pleural liquid withdrawn $3 \mathrm{~h}$ after instillation of asbestos with $\mathrm{F}\left(\mathrm{ab}^{\prime}\right)_{2}$ fragments of the anti-IL-8 MAb $(100 \mu \mathrm{g} / \mathrm{ml})$ reduced neutrophil migration by $72 \pm 8 \%(P<0.05)$. Similar treatment with $\mathrm{F}\left(\mathrm{ab}^{\prime}\right)_{2}$ fragments of an anti-IL-6 MAb did not affect chemotactic activity. Data are mean values $( \pm$ SE) obtained in five experiments. Net neutrophil migration in response to $1.0 \mathrm{nM}$ FMLP in these experiments was $64 \pm 5 \mu \mathrm{m} / 40 \mathrm{~min}$. 


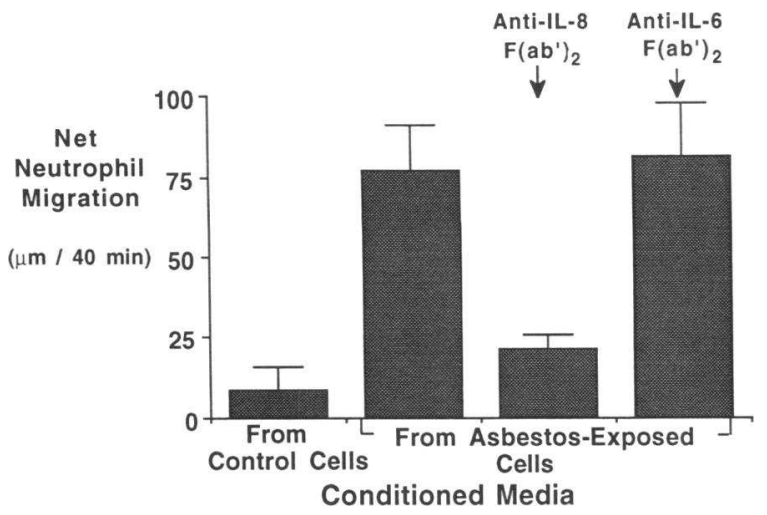

Figure 4. Neutralization of chemotactic activity in conditioned media from asbestos-stimulated pleural mesothelial cells by incubation with $\mathrm{F}\left(\mathrm{ab}^{\prime}\right)_{2}$ fragments of the anti-IL-8 MAb, A.5.12.14. Net neutrophil migration was significantly greater in response to conditioned media from rabbit pleural mesothelial cells exposed to asbestos $(30 \mu \mathrm{g} / \mathrm{ml})$ for $2 \mathrm{~h}$ compared with media from cells cultured alone (control cells) $(P<0.05)$. Incubation of conditioned media from asbestos-stimulated mesothelial cells with $\mathrm{F}\left(\mathrm{ab}^{\prime}\right)_{2}$ fragments of MAb A.5.12.14 (100 $\mu \mathrm{g} / \mathrm{ml})$ reduced neutrophil migration by $70 \pm 7 \%(P<0.05)$. Similar treatment with $\mathrm{F}\left(\mathrm{ab}^{\prime}\right)_{2}$ fragments of an anti-IL-6 MAb did not affect chemotactic activity. Data represent mean values $( \pm S E)$ obtained in four experiments. Net neutrophil migration in response to $1.0 \mathrm{nM}$ FMLP in these experiments was $81 \pm 12 \mu \mathrm{m} / 40 \mathrm{~min}$.

neutrophils recovered from the pleural spaces exposed to TNF was more than threefold greater than that from the opposite side (Table I). There was no increase in the entry of radiolabeled protein. Chemotactic activity was detected in pleural liquid at $2 \mathrm{~h}$ and was maximal by $4 \mathrm{~h}$ (net neutrophil migration $26 \pm 8$ and $66 \pm 7 \mu \mathrm{m} / 40 \mathrm{~min}$, respectively, versus net migration to the instillates alone $4 \pm 3 \mu \mathrm{m} / 40 \mathrm{~min} ; n=5$ ). Furthermore, the chemotactic activity that appeared in pleural liquid at $4 \mathrm{~h}$ was inhibited significantly by incubation with MAb A.5.12.14 (by $82 \pm 9 \%$, mean \pm SE, $n=5$ ), but not with the control myeloma protein, RPC 5 (by $-3 \pm 9 \%$ ).

There was no difference in measured physiologic parameters among the three groups of rabbits (asbestos-exposed, TNFexposed, and controls). For all experiments, mean arterial blood pressure was $70 \pm 5 \mathrm{mmHg}$ (mean $\pm \mathrm{SD}$ ), central venous pressure was $5 \pm 1 \mathrm{cmH}_{2} \mathrm{O}$, rectal temperature was $39.2 \pm 0.2^{\circ} \mathrm{C}$, arterial $\mathrm{pH}$ was $7.39 \pm 0.06$, arterial $\mathrm{PCO}_{2}$ was $38 \pm 7 \mathrm{mmHg}$, and arterial $\mathrm{PO}_{2}$ was $295 \pm 42 \mathrm{mmHg}$. Following instillation of liquid into pleural spaces bilaterally, there was no change in airway pressure, but there was a transient and significant increase in $\mathrm{PCO}_{2}$ of $3 \pm 4 \mathrm{mmHg}$.

Stimulation of rabbit pleural mesothelial cells with asbestos and TNF. Conditioned media from mesothelial cells exposed for $2 \mathrm{~h}$ to asbestos (Fig. 4) or TNF (see below) contained significant chemotactic activity for rabbit neutrophils. Neither asbestos alone $(30 \mu \mathrm{g} / \mathrm{ml})$, TNF alone $(20 \mathrm{ng} / \mathrm{ml})$, nor medium from either unstimulated cells (net neutrophil migration $9 \pm 8 \mu \mathrm{m} / 40$ $\min ; n=3$ ), cells exposed to glass beads $(7 \pm 2 \mu \mathrm{m} / 40 \mathrm{~min} ; n$ $=3)$, or cells exposed to asbestos filtrate $(3 \pm 4 \mu \mathrm{m} / 40 \mathrm{~min} ; n$ $=3$ ) induced an increase in neutrophil migration. By checkerboard analysis, samples of conditioned media from mesothelial cells exposed to asbestos (Table II) or to TNF (data not shown) contained primarily chemotactic, rather than chemokinetic, activity $(n=3, P=0.042)$. Heating conditioned media (from cells exposed to TNF) to $56^{\circ}$ for 30 min reduced chemotactic activity by $33 \pm 14 \%($ mean $\pm \mathrm{SE}, n=3)$; heating to $100^{\circ} \mathrm{C}$ for 30 min eliminated all chemotactic activity. Mesothelial cells exposed to asbestos or TNF for $6 \mathrm{~h}$ remained viable, i.e., did not exhibit morphologic changes detectable by phase-contrast microscopy and did not release greater amounts of lactate dehydrogenase than did control cells exposed to serum-free medium alone: asbestos, $7 \pm 4 \%$ (mean $\pm \mathrm{SD}$ ) of total lactate dehydrogenase activity $(n=4)$; TNF, $4 \pm 1 \%(n=4)$; control, $5 \pm 4 \%(n$ $=4)$.

Incubation with $\mathrm{F}\left(\mathrm{ab}^{\prime}\right)_{2}$ fragments of MAb A.5.12.14 (100 $\mu \mathrm{g} / \mathrm{ml}$ ) significantly decreased chemotactic activity in conditioned media from asbestos-stimulated pleural mesothelial cells (by $70 \pm 7 \%$ ) (Fig. 4). Incubation with $\mathrm{F}\left(\mathrm{ab}^{\prime}\right)_{2}$ fragments of the anti-IL-6 MAb had no effect (Fig. 4). Chemotactic activity from TNF-stimulated cells also was reduced significantly when incubated with MAb A.5.12.14 (net migration reduced from $72 \pm 6$ to $21 \pm 4 \mu \mathrm{m} / 40 \mathrm{~min}$ ), but not with the isotype-matched, control myeloma protein (to $68 \pm 7 \mu \mathrm{m} / 40 \mathrm{~min}$ ). The specificity of these findings was confirmed by the inability of $\mathrm{MAb}$ A.5.12.14 to decrease net neutrophil migration in response to

Table II. Effects of Conditioned Medium from Mesothelial Cells Exposed to Asbestos on Neutrophil Migration (Checkerboard Analysis)

\begin{tabular}{|c|c|c|c|c|}
\hline & \multicolumn{4}{|c|}{ Concentrations of conditioned medium in upper wells } \\
\hline & 0 & $1 \%$ & $10 \%$ & $100 \%$ \\
\hline & \multicolumn{4}{|c|}{$\mu m / 40 \mathrm{~min}$} \\
\hline \multicolumn{5}{|c|}{$\begin{array}{l}\text { Concentrations of conditioned } \\
\text { medium in lower wells }\end{array}$} \\
\hline $0 \%$ & $8 \pm 2$ & $17 \pm 6$ & $11 \pm 3$ & $3 \pm 4$ \\
\hline $1 \%$ & $13 \pm 6$ & $14 \pm 4$ & $14 \pm 8$ & $-9 \pm 3$ \\
\hline $10 \%$ & $24 \pm 16$ & $21 \pm 11$ & $14 \pm 8$ & $-2 \pm 4$ \\
\hline $100 \%$ & $90 \pm 11$ & $49 \pm 12$ & $26 \pm 13$ & $-14 \pm 3$ \\
\hline
\end{tabular}

Results represent net neutrophil migration, i.e., migration of rabbit neutrophils in response to varying concentrations of conditioned medium from mesothelial cells incubated with asbestos $(30 \mu \mathrm{g} / \mathrm{ml})$ for $2 \mathrm{~h}$ minus migration in response to buffer alone. Data are mean values $\pm \mathrm{SE}$. Net migration in response to a positive gradient of conditioned medium was significantly greater than that observed when concentrations of conditioned medium were the same in the upper and lower wells by Student's $t$ test $(P=0.042)$. Net neutrophil migration in response to $1.0 \mathrm{nM}$ FMLP in these experiments was $101 \pm 11 \mu \mathrm{m} / 40 \mathrm{~min}$. 
$1.0 \mathrm{nM}$ FMLP (FMLP alone, $62 \pm 6 \mu \mathrm{m} / 40 \mathrm{~min}$; FMLP plus A.5.12.14, $54 \pm 7 \mu \mathrm{m} / 40 \mathrm{~min} ; n=4$ ).

Isolation of a rabbit IL-8 cDNA fragment. Homology-based PCR yielded a single product from the cDNA of stimulated rabbit pleural mesothelial cells (TNF $20 \mathrm{ng} / \mathrm{ml}, 24 \mathrm{~h}$ ), but not from unstimulated mesothelial cells. All recombinant clones analyzed contained 185 -bp inserts with the same nucleotide sequence. The nucleotide sequence was $88 \%$ identical to that of the corresponding region of human IL- 8 cDNA (18), and the deduced amino acid sequences were $89 \%$ identical. In addition, the nucleotide sequence of this fragment subsequently was found to be identical to bases 117-229 of a recently published rabbit IL-8 cDNA sequence (23).

Induction of IL-8 gene expression in pleural mesothelial cells by asbestos and TNF. Northern blot analysis, using the labeled rabbit IL-8 cDNA fragment as a probe, revealed a single mRNA species of $\sim 1.8 \mathrm{~kb}$ in pleural mesothelial cells exposed to asbestos or TNF, but not in cells incubated with serum-free medium alone. IL-8 mRNA expression was evident $2 \mathrm{~h}$ after exposure to asbestos or TNF; after exposure to asbestos, IL-8 mRNA expression continued to increase over the $6 \mathrm{~h}$ studied (Fig. 5).

\section{Discussion}

In this report, we have shown that crocidolite asbestos stimulates cultured mesothelial cells to produce the potent chemotactic factor IL-8, and our results suggest that mesothelial cellderived IL-8 plays an important role in mediating asbestos-induced pleural inflammation. To our knowledge, we are the first to show that IL-8 is produced either in vitro or in vivo after exposure to asbestos, and that IL-8 contributes significantly to chemotactic activity generated in vivo.

First, we confirmed the findings of others (4) that instillation of crocidolite asbestos into the pleural spaces of rabbits induces a significant influx of neutrophils (Table I, Fig. $2 \mathrm{~A}$ ) as well as the appearance in pleural liquid of chemotactic activity

TNF

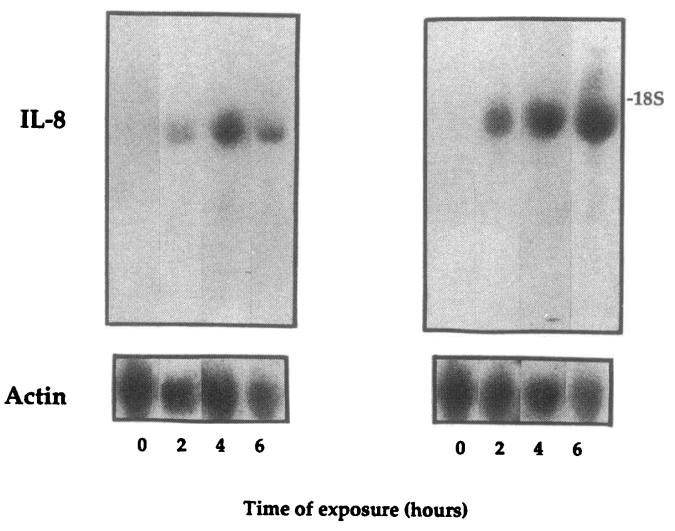

Figure 5. Northern blot analysis of IL-8 mRNA expressed in TNFand asbestos-stimulated rabbit pleural mesothelial cells. IL-8 mRNA was not detected in unstimulated cells, but was detected in cells incubated for $2 \mathrm{~h}$ with either TNF or asbestos. Similar expression of mRNA for $\beta$-actin demonstrates that similar amounts of mRNA were loaded in each lane. for neutrophils (Fig. 2 B). In these experiments, we were concerned about contamination of the instillates with endotoxin, to which the rabbit pleural space is exquisitely sensitive. Indeed, it has been reported that instillation of as little as $50 \mathrm{ng}$ of $E$. coli endotoxin into the pleural spaces of rabbits induces a large influx of neutrophils (24). Consequently, the crocidolite asbestos used in our experiments was treated to eliminate endotoxin; stock suspensions of asbestos prepared in this way, as well as conditioned medium and instillates, contained undetectable levels of endotoxin. The addition of polymixin at a concentration that can bind much higher levels of endotoxin did not ablate the effect of asbestos. Interestingly, instillation of asbestos into the pleural space caused a small, but significant, increase in protein entry (Table I) unexplained by changes in vascular pressures or by a leak of blood. Similar small increases in entry of protein have been associated with the entry of neutrophils into the lung in response to the chemotactic factor, $\operatorname{LTB}_{4}(25,26)$.

Second, we demonstrated that the bulk of chemotactic activity in pleural liquid after asbestos was instilled could be inhibited by incubation with $\mathrm{F}\left(\mathrm{ab}^{\prime}\right)_{2}$ fragments of a MAb to human IL-8 (Fig. 3). It should be emphasized that the MAb used in these studies was directed against human, not rabbit, IL-8. It was fortunate, therefore, that the antibody blocked the chemotactic activity of rabbit IL-8, but not unexpected given the high degree of homology of IL-8 among different species (23). In fact, it is possible that an antibody directed against rabbit IL-8 might have neutralized more of the asbestos-induced chemotactic activity than did the antibody directed against human IL-8. We assume that this antibody is as specific for rabbit IL-8 as it is for human IL-8 by not crossreacting with other members of the macrophage inflammatory protein family, specifically platelet factor 4 and $\beta$-thromboglobulin (27). Even if the antihuman IL-8 MAb did crossreact with these closely related proteins in the rabbit, it is unlikely that they contributed to the chemotactic activity that we detected in pleural liquid because platelet factor 4 is a relatively weak neutrophil chemotactic factor (28) and $\beta$-thromboglobulin has no neutrophil chemotactic activity (29).

Third, after confirming the findings of others (8) that incubation of cultured rabbit pleural mesothelial cells with asbestos causes the appearance of chemotactic activity in conditioned medium (Table II, Fig. 4), we demonstrated that the bulk of this chemotactic activity is attributable to IL-8 (Fig. 4). Since chemotactic activity was not produced after exposure to asbestos filtrate or glass beads, we conclude that some aspect of the asbestos particle itself induced production of IL-8. It may be the crystalline structure or the geometry of the asbestos fiber that is important for generation of IL-8. Since other crystals such as urate and silica induce IL-8 production by monocytes (30), we cannot exclude the possibility that these crystals would also induce production of IL-8 by mesothelial cells.

Fourth, using a specific rabbit IL-8 cDNA probe, we demonstrated that rabbit pleural mesothelial cells stimulated with asbestos in vitro, but not unstimulated mesothelial cells, contain IL-8 transcripts (Fig. 5). It is not likely that cells other than mesothelial cells in our cultures contributed to these results or to those described above. Although there is no single identifying marker for mesothelial cells, other cells could be excluded by several tests. The cultured cells stained negatively for nonspecific esterase and factor VIII, while rabbit macrophages and endothelial cells, respectively, stained positively. The cultured 
cells also stained for both intermediate filaments, vimentin and keratin (Fig. 1), considered a unique feature of mesothelial cells (31). Furthermore, the large quantity of message detected by Northern analysis suggests strongly that many cells, not just a few contaminants, were the source of the mRNA encoding IL-8.

Finally, we found that a more general stimulus, the macrophage-derived cytokine TNF also induces an influx of neutrophils into the pleural space as well as the production of IL-8 both in vivo and in vitro (Table I, Figs. 2 and 5). The fact that experiments performed in vivo and in vitro with two different stimuli yielded similar results lends support to our conclusion that mesothelial cell-derived IL-8 probably plays an important role in mediating pleural inflammation.

Asbestos is an important cause of pleural and lung disease in man, capable of causing chronic inflammation, fibrosis, and cancer. One of the earliest biologic responses to asbestos appears to be the recruitment of neutrophils. This neutrophil influx may be important for the development of later pathologic responses $(3,32)$. In humans with a history of asbestos exposure, a neutrophilia has been detected in bronchoalveolar lung lavage (1) and in pleural effusions (33). In animal models, neutrophilia can be produced by introducing asbestos fibers into the airspaces (2), into the peritoneal space (34), or into the pleural spaces $(4,35)$. Of note, in other studies (8) as well as in our own, asbestos itself did not exhibit chemotactic activity. Consequently, it is the interaction of asbestos with cells or serum that is necessary for the generation of chemotactic activity for neutrophils.

Asbestos is known to induce the generation of several chemotactic factors for neutrophils: C5a (from serum) (36); leukotriene $\mathrm{B}_{4}$ and a $1-\mathrm{kD}$ chemotactic factor (from alveolar macrophages) $(37,38)$; and a $6-9-\mathrm{kD}$ chemotactic peptide (from pleural mesothelial cells) (8). We have now shown that asbestos directly induces production of IL- 8 by pleural mesothelial cells in vitro, and that, whether directly or indirectly, asbestos also induces the production of IL- 8 in vivo. Asbestos in vivo could act indirectly by causing the generation of pleural macrophagederived cytokines, which, in turn, could stimulate pleural mesothelial cells to generate IL-8. Since asbestos is known to stimulate macrophages to produce TNF and IL-1 (39-41), it is possible that it did so in the pleural space. Because of the lack of availability of neutralizing antibodies to rabbit TNF or IL-1 $\beta$, we were unable to test whether these cytokines played an intermediate role.

We do not know how much of the IL- 8 that we detected in the experiments performed in vivo was produced by pleural mesothelial cells. IL- 8 could also have been produced by pleural macrophages, lymphocytes, or subpleural fibroblasts. To estimate the contribution of mesothelial cells, conditions for the in vitro and in vivo experiments were made as similar as possible. The cell culture dishes that we used had a surface area $\left(176 \mathrm{~cm}^{2}\right)$ very similar to the surface area of the pleura which lines one rabbit pleural space $\left(182 \mathrm{~cm}^{2}\right)(42)$. The concentrations of asbestos and TNF and the volume of medium $(10 \mathrm{ml})$ were the same for both the in vitro and in vivo experiments. The similar amounts of chemotactic activity that we detected suggests that it is possible that pleural mesothelial cells could have produced all of the IL-8 found in vivo.

Although macrophages are a likely source of IL-8, evidence to date has failed to show that either pleural macrophages exposed to endotoxin or alveolar macrophages exposed to asbes- tos produce an IL-8-like factor. In a study of endotoxin-induced pleurisy in the rabbit, pleural macrophages harvested after endotoxin exposure produced two factors that caused an influx of neutrophils when injected intradermally, one of 14$18 \mathrm{kD}$ and the other of $45 \mathrm{kD}$ (24). Although the 14-18-kD factor could have been a dimer of IL-8, this seems unlikely since the factor did not exhibit chemotactic activity in vitro. When alveolar macrophages were exposed to crocidolite asbestos $(100 \mu \mathrm{g} / \mathrm{ml})$ for $4 \mathrm{~h}$, gel filtration of the conditioned medium failed to yield a chemotactic peptide with physical properties similar to those of IL-8 (38). Failure to detect generation of IL-8 after exposure to asbestos is surprising given that alveolar macrophages produce IL-8 in response to other stimuli, such as TNF and IL-1 (43). It is possible, however, that pleural mesothelial cells are more sensitive to stimulation with asbestos than are alveolar macrophages (44). Thus, experimental evidence so far supports an important role for mesothelial cells as the source for pleural IL-8.

Several properties of IL-8 make it a likely mediator of extravascular recruitment of neutrophils into the pleural space in response to a variety of pleural insults. It is specifically chemotactic for neutrophils, activating them and inducing expression of CD11/CD18 adhesion receptors on their surfaces (45). IL-8 protein is resistant to degradation by proteinases and, compared with cellular expression of some cytokines such as TNF, cellular expression of mRNA encoding IL-8 is long-lasting (46). Finally, we suspect that IL-8 may play a role in mediating pleural inflammation in general because it is produced by mesothelial cells after stimulation with TNF, a likely product of many different inflammatory stimuli.

There is suggestive evidence from other studies that IL-8 may participate in mediating several types of pleural inflammation. For example, in a study of pleurisy induced by carrageenan and kaolin, Lynn and coworkers (47) found that almost $90 \%$ of the chemotactic activity in pleural liquid could be accounted for by proteins of 5-8 kD and 20-25 kD. IL-8 could represent the 5-8-kD chemotactic proteins found in this study. In many other studies of pleural inflammation $(4,24,48,49)$, as well as in our own, neutrophil influx in response to instillation of various stimuli typically followed a lag period of $30 \mathrm{~min}$ to $2 \mathrm{~h}$. The lag period suggests a major role for protein synthesis and a minor role, if any, for chemotactic factors that are generated immediately or within minutes after exposure to asbestos, such as complement-derived peptides (e.g., C5a) or leukotriene $B_{4}(50)$. In the peritoneal space, which is similarly lined by mesothelial cells, IL- 8 has recently been isolated by protein purification methods from peritoneal liquid after induction of inflammation with zymosan (51). Consequently, diverse inflammatory stimuli may induce generation of IL-8, and IL-8 may be a common mediator of acute pleural inflammation.

In this report, we describe a novel method for studying inflammation in vivo, which permits access to the pleural space via a minimally invasive, noninjurious transdiaphragmatic catheter (15). Using this continuous access to the pleural space, we can instill and withdraw samples repeatedly without resorting to multiple thoracenteses or an indwelling catheter advanced alongside the fragile visceral pleura. We believe this explains why our control values for neutrophil counts are lower than those obtained by others using different techniques to access the pleural space. For example, in one study in which a catheter was advanced into the pleural space of rabbits, 20 $\times 10^{6}$ neutrophils were recovered $4 \mathrm{~h}$ after the injection of $5 \mathrm{ml}$ 
of saline (4), as compared with our recovery at $6 \mathrm{~h}$ of $1.9 \times 10^{6}$ neutrophils (Table I). In another study (24), the neutrophil count was $4,000-5,000 / \mu \mathrm{l} 4 \mathrm{~h}$ after the instillation of $10 \mathrm{ml}$ of Tyrode's solution compared with the neutrophil count of $102 \pm 81 / \mu$ l that we observed at $4 \mathrm{~h}$ (Fig. $2 \mathrm{~A}$ ). Furthermore, we can measure baseline pleural liquid counts to assure that the pleural space is uninflamed; indeed, our baseline pleural liquid cell counts $(1,900 \pm 1,400$ cells $/ \mu \mathrm{l})$ are similar to reported normal values $(1,500 \pm 280$ cells $/ \mu 1)(22)$. The number of erythrocytes in the pleural liquid was also very low, $<1500$ cells $/ \mu l$ in all experiments. This value cannot be compared with those obtained in other models of pleural inflammation since erythrocyte counts generally have not been reported. Of note, the pleural space is one of the few sites in the body where inflammatory liquid can be collected and studied. Using this catheter method, we anticipate multiple uses for the study of inflammation.

In conclusion, we have shown that pleural mesothelial cells produce IL-8 directly after exposure to asbestos fibers. This represents the first demonstration that asbestos can stimulate the production of this potent neutrophil chemotactic factor. We have further shown that, in the pleural space, IL-8 contributes significantly to the chemotactic activity generated in vivo. Mesothelial cell-derived IL-8 may play an important role in mediating many types of pleural inflammation, including that due to asbestos.

\section{Acknowledgments}

The authors thank Fred Ousley for his assistance with cell culture and F. Joseph Roll, M.D., for his patient instruction in the performance of the chemotactic assays.

This work was supported by grants from the National Institutes of Health (HL-19155 [Pulmonary Vascular SCOR], HL-28616, HL/AI33259), the Treadwell Foundation, and the University of California Tobacco-related Disease Research Program (1 RT 338). Dr. Boylan was supported by an NIH Individual National Research Service Award (HL-08280). Dr. Rüegg was supported by a fellowship from the Swiss National Science Foundation. Dr. Broaddus was supported by an NIH Clinical Investigator Award (HL-01893).

Note added in proof. After the submission of the manuscript for this article, it was reported that cultured human plural mesothelial cells can produce IL-8 (52).

\section{References}

1. Robinson, B. W. S., A. H. Rose, A. James, D. Whitaker, and A. W. Musk 1986. Alveolitis of pulmonary asbestosis: bronchoalveolar lavage studies in crocidolite- and chrysotile-exposed individuals. Chest. 90:396-402.

2. Rola-Pleszczynski, M., S. Gouin, and R. Bégin. 1984. Asbestos-induced lung inflammation: role of local macrophage-derived chemotactic factors in accumulation of neutrophils in the lungs. Inflammation. 8:53-62.

3. Mossman, B. T., and J. B. L. Gee. 1989. Asbestos-related diseases. N. Engl. J. Med. 320:1721-1730.

4. Shore, B. L., C. C. Daughaday, and I. Spilberg. 1983. Benign asbestos pleurisy in the rabbit: a model for the study of pathogenesis. Am. Rev. Respir. Dis. 128:481-485.

5. Jaurand, M.-C., H. Kaplan, J. Thiollet, M.-C. Pinchon, J.-F. Bernaudin, and J. Bignon. 1979. Phagocytosis of chrysotile fibers by pleural mesothelial cells in culture. Am. J. Pathol. 94:529-538.

6. Coene, M.-C., C. Van Hove, M. Claeys, and A. G. Herman. 1982. Arachidonic acid metabolism by cultured mesothelial cells. Biochim. Biophys. Acta. 710:437-445.

7. Lambert, R. S., A. P. Baumann, G. T. Kinasewitz, and F. B. Gelder. 1988.
Interferon induces immune expression by cultured human pleural mesothelial cells. Am. Rev. Respir. Dis. 137:45. (Abstr.)

8. Antony, V. B., C. L. Owen, and K. J. Hadley. 1989. Pleural mesothelial cells stimulated by asbestos release chemotactic activity for neutrophils in vitro. Am. Rev. Respir. Dis. 139:199-206.

9. Yoshimura, T., K. Matsushima, J. J. Oppenheim, and E. J. Leonard. 1987. Neutrophil chemotactic factor produced by lipopolysaccharide (LPS)-stimulated human blood mononuclear leukocytes: partial characterization and separation from interleukin 1 (IL-1). J. Immunol. 139:788-793.

10. Walz, A., P. Peveri, H. Aschauer, and M. Baggiolini. 1987. Purification and amino acid sequencing of NAF, a novel neutrophil-activating factor produced by monocytes. Biochem. Biophys. Res. Commun. 149:755-761.

11. Strieter, R. M., S. H. Phan, H. J. Showell, D. G. Remick, J. P. Lynch, M. Genord, C. Raiford, M. Eskandari, R. M. Marks, and S. L. Kunkel. 1989. Monokine-induced neutrophil chemotactic factor gene expression in human fibroblasts. J. Biol. Chem. 264:10621-10626.

12. Thornton, A. J., R. M. Strieter, I. Lindley, M. Baggiolini, and S. L. Kunkel. 1990. Cytokine-induced gene expression of a neutrophil chemotactic factor/ IL-8 in human hepatocytes. J. Immunol. 144:2609-2613.

13. Strieter, R. M., S. L. Kunkel, H. J. Showell, D. G. Remick, S. H. Phan, P. A. Ward, and R. M. Marks. 1989. Endothelial cell gene expression of a neutrophil chemotactic factor by TNF- $\alpha$, LPS, and Il-1 $\beta$. Science (Wash. DC) 243:1467-1469.

14. Standiford, T. J., S. L. Kunkel, M. A. Basha, S. W. Chensue, J. P. Lynch III, G. B. Toews, J. Westwick, and R. M. Strieter. 1990. Interleukin-8 gene expression by a pulmonary epithelial cell line: a model for cytokine networks in the lung. J. Clin. Invest. 86:1945-1953.

15. Broaddus, V. C., and M. Araya. 1992. Liquid and protein dynamics using a new, minimally invasive pleural catheter in rabbits. J. Appl. Physiol. 72:851857.

16. Campbell, W. J., C. W. Huggins, and A. G. Wylie. 1980. Chemical and Physical Characterization of Amosite, Chrysotile, Crocidolite, and Nonfibrous Tremolite for Oral Ingestion Studies by the National Institute of Environmental Health Sciences. No. 8452. 1-63. US Government Printing Office, Pittsburgh, PA.

17. Zigmond, S. H., and J. G. Hirsch. 1973. Leukocyte locomotion and chemotaxis: new methods for evaluation, and demonstration of a cell-derived chemotactic factor. J. Exp. Med. 137:387-410.

18. Matsushima, K., K. Morishita, T. Yoshimura, S. Lavu, Y. Kobayashi, W. Lew, E. Appella, H. F. Kung, E. J. Leonard, and J. J. Oppenheim. 1988. Molecular cloning of a human monocyte-derived neutrophil chemotactic factor (MDNCF) and the induction of MCNCF mRNA by interleukin-1 and tumor necrosis factor. J. Exp. Med. 167:1883-1893.

19. Sanger, F., S. Nicklen, and A. R. Coulson. 1977. DNA sequencing with chain-terminating inhibitors. Proc. Natl. Acad. Sci. USA. 74:5463-5467.

20. SuperAnova. 1989. Abacus Concepts, Inc., Berkeley, CA

21. Zar, J. H. 1984. Biostatistical Analysis. Prentice-Hall, Inc., Englewood Cliffs, NJ. 718 pp.

22. Stauffer, J. L., D. E. Potts, and S. A. Sahn. 1978. Cellular content of the normal rabbit pleural space. Acta Cytol. 22:570-574.

23. Yoshimura, T., and N. Yuhki. 1991. Neutrophil attractant/activation protein-1 and monocyte chemoattractant protein-1 in rabbit: cDNA cloning and their expression in spleen cells. J. Immunol. 146:3483-3488.

24. Issekutz, A. C., P. Megyeri, and T. B. Issekutz. 1987. Role for macrophage products in endotoxin-induced polymorphonuclear leukocyte accumulation during inflammation. Lab. Invest. 56:49-59.

25. Staub, N. C., E. L. Schultz, K. Koike, and K. H. Albertine. 1985. Effect of neutrophil migration induced by leukotriene $\mathrm{B}_{4}$ on protein permeability in sheep lung. Fed. Proc. 44:30-35.

26. Martin, T. R., B. P. Pistorese, E. Y. Chi, R. B. Goodman, and M. A. Matthay. 1989. Effects of leukotriene $B_{4}$ in the human lung: recruitment of neutrophils into the alveolar spaces without a change in protein permeability. J. Clin. Invest. 84:1609-1619.

27. Wolpe, S. D., and A. Cerami. 1989. Macrophage inflammatory proteins 1 and 2: members of a novel superfamily of cytokines. FASEB J. 3:2565-2573.

28. Deuel, T. F., R. M. Senior, D. Chang, G. L. Griffin, R. L. Heinrikson, and E. T. Kaiser. 1981. Platelet factor 4 is chemotactic for neutrophils and monocytes. Proc. Natl. Acad. Sci. USA. 78:4584-4587.

29. Van Damme, J., M. Rampart, R. Conings, B. Dedock, N. Van Osselaer, J. Willems, and A. Billiau. 1990. The neutrophil-activating proteins interleukin 8 and $\beta$-thromboglobulin: in vitro and in vivo comparison of $\mathrm{NH}_{2}$-terminally processed forms. Eur. J. Immunol. 20:2113-2118.

30. Terkeltaub, R., C. Zachariae, D. Santoro, J. Martin, P. Peveri, and K. Matsushima. 1991. Monocyte-derived neutrophil chemotactic factor/interleukin-8 is a potential mediator of crystal-induced inflammation. Arthritis Rheum. 34:894-903.

31. Connell, N. D., and J. G. Rheinwald. 1983. Regulation of the cytoskeleton in mesothelial cells: reversible loss of keratin and increase in vimentin during rapid growth in culture. Cell. 34:245-253. 
32. Rebuck, A. S., and A. C. Braude. 1983. Bronchoalveolar lavage in asbestosis. Arch. Intern. Med. 143:950-952.

33. Robinson, B. W. S., and A. W. Musk. 1981. Benign asbestos pleural effusion: diagnosis and course. Thorax. 36:896-900.

34. Moalli, P. A., J. L. MacDonald, L. A. Goodglick, and A. B. Kane. 1987. Acute injury and regeneration of the mesothelium in response to asbestos fibers. Am. J. Pathol. 128:426-445.

35. Sahn, S. A., and V. B. Antony. 1984. Pathogenesis of pleural plaques: relationship of early cellular response and pathology. Am. Rev. Respir. Dis. 130:884-887.

36. Wilson, M. R., H. R. Gaumer, and J. E. Salvaggio. 1977. Activation of the alternative complement pathway and generation of chemotactic factors by asbestos. J. Allergy Clin. Immunol. 60:218-222.

37. Kouzan, S., A. R. Brody, P. Nettesheim, and T. Eling. 1985. Production of arachidonic acid metabolites by macrophages exposed in vitro to asbestos, carbonyl iron particles, or calcium ionophore. Am. Rev. Respir. Dis. 131:624-632.

38. Hayes, A. A., T. J. Venaille, A. H. Rose, A. W. Musk, and B. W. S. Robinson. 1990. Asbestos-induced release of a human alveolar macrophage-derived neutrophil chemotactic factor. Exp. Lung Res. 16:121-130.

39. Dubois, C. M., E. Bissonnette, and M. Rola-Pleszczynski. 1989. Asbestos fibers and silica particles stimulate rat alveolar macrophages to release tumor necrosis factor. Am. Rev. Respir. Dis. 139:1257-1264.

40. Bissonnette, E., and M. Rola-Pleszczynski. 1989. Pulmonary inflammation and fibrosis in a murine model of asbestosis and silicosis: possible role of tumor necrosis factor. Inflammation. 13:329-339.

41. Oghiso, Y., and Y. Kubota. 1987. Interleukin-1 production and accessory cell function of rat alveolar macrophages exposed to mineral dust particles. Microbiol. Immunol. 31:275-287.

42. Miserocchi, G., and E. Agostoni. 1971. Contents of the pleural space. $J$. Appl. Physiol. 30:208-213.

43. Strieter, R. M., S. W. Chensue, M. A. Basha, T. J. Standiford, J. P. Lynch III, M. Baggiolini, and S. L. Kunkel. 1990. Human alveolar macrophage gene expression of interleukin- 8 by tumor necrosis factor- $\alpha$, lipopolysaccharide, and interleukin-1 B. Am. J. Respir. Cell. Mol. Biol. 2:321-326.
44. Lechner, J. F., T. Tokiwa, M. LaVeck, W. F. Benedict, S. Banks-Schlegel, H. Yeager, Jr., A. Banerjee, and C. C. Harris. 1985. Asbestos-associated chromosomal changes in human mesothelial cells. Proc. Natl. Acad. Sci. USA. 82:38843888.

45. Detmers, P. A., S. K. Lo, E. Olsen-Egbert, A. Wa'ż, M. Baggiolini, and Z. A. Cohn. 1990. Neutrophil-activating protein $1 /$ interlei kin-8 stimulates the binding activity of the leukocyte adhesion receptor CD1/b/CD18 on human neutrophils. J. Exp. Med. 171:1155-1162.

46. Baggiolini, M., A. Walz, and S. L. Kunkel. 1989. Neutrophil-activating peptide-1/interleukin-8, a novel cytokine that activates neutrophils. J. Clin. Invest. 84:1045-1049.

47. Lynn, W. S., R. S. N. Somayajulu, S. Sahu, and J. Selph. 1978. Characterization of chemotactic agents produced in experimental pleural inflammation. In Leukocyte Chemotaxis. J. I. Gallin and P. G. Quie, editors. Raven Press, New York. 299-306.

48. Glatt, M., P. Dieppe, and D. Willoughby. 1979. Crystal-induced inflammation, enzyme release and the effects of drugs in the rat pleural space. J. Rheumatol. 6:251-258.

49. Vinegar, R., J. F. Truax, J. L. Selph, and F. A. Voelker. 1982. Pathway of onset, development, and decay of carrageenan pleurisy in the rat. Fed. Proc. 41:2588-2595.

50. Cybulsky, M. I., D. J. McComb, and H. Z. Movat. 1989. Protein synthesis dependent and independent mechanisms of neutrophil emigration: different mechanisms of inflammation in rabbits induced by interleukin-1, tumor necrosis factor alpha, or endotoxin versus leukocyte chemoattractants. Am. J. Pathol. 135:227-237.

51. Beaubien, B. C., P. D. Collins, P. J. Jose, N. F. Totty, J. Hsuan, M. D. Waterfield, and T. J. Williams. 1990. A novel neutrophil chemoattractant generated during an inflammatory reaction in the rabbit peritoneal cavity in vivo: purification, partial amino acid sequence and structural relationship to interleukin 8. Biochem. J. 271:797-801.

52. Goodman, R. B., R. G. Wood, T. R. Martin, O. Hanson-Painton, G. T. Kinasewitz. 1992. Cytokine-stimulated human nesothelial cells produce chemotactic activity for neutrophils including NAP-1/IL-8. J. Immunol. 148:457-465. 